\title{
The Synthesis and Stability Study of Silver Nanoparticles Prepared Using p-Aminobenzoic Acid as Reducing and Stabilizing Agent
}

\author{
Dian Susanthy, Sri Juari Santosa*, and Eko Sri Kunarti \\ Department of Chemistry, Faculty of Mathematics and Natural Sciences, Universitas Gadjah Mada, \\ Sekip Utara, Yogyakarta 55281, Indonesia
}

Received October 25, 2017; Accepted February 5, 2018

\begin{abstract}
A study to examine the performance of p-aminobenzoic acid as both reducing agent for silver nitrate to silver nanoparticles (AgNPs) and stabilizing agent for the formed AgNPs has been done. The synthesis of AgNPs was performed by mixing silver nitrate solution as precursor with $p$-aminobenzoic acid solution and heating it in a boiling water bath. After the solution turned to yellow, the reaction was terminated by cooling it in tap water. The formed AgNPs were analyzed by using UV-Vis spectrophotometry to evaluate their surface plasmon resonance (SPR) absorption in wavelength range of 400-500 $\mathrm{nm}$. The synthesis process was highly affected by $\mathrm{pH}$, reaction time, and mole ratios of the reactants. The synthesis was only successful at $\mathrm{pH} 11$ and at reaction time 30 min, the particle size of the formed AgNPs was $12 \pm 7 \mathrm{~nm}$. Longer reaction time increased the reducing performance of $p$ aminobenzoic acid in AgNPs synthesis but decreased its stabilizing performance. The increase of silver nitrate amount relative to $p$-aminobenzoic acid in the synthesis increased the reducing and stabilizing performance of $p$ aminobenzoic acid and the optimum mole ratio $\mathrm{AgNO}_{3}$ to $\mathrm{p}$-aminobenzoic acid was 5:100.
\end{abstract}

Keywords: p-aminobenzoic acid; reducing agent; silver nanoparticle; stabilizing agent

\section{ABSTRAK}

Penelitian ini mengkaji tentang kemampuan asam p-aminobenzoat sebagai agen pereduksi bagi perak nitrat untuk menjadi nanopartikel perak (AgNPs) dan sekaligus sebagai agen penstabil bagi AgNPs yang terbentuk. Sintesis dilakukan dengan mencampur larutan perak nitrat sebagai prekursor dengan larutan asam p-aminobenzoat kemudian memanaskannya di penangas air mendidih. Setelah larutan berubah warna menjadi kuning, reaksi dihentikan dengan mendinginkan larutan dalam air mengalir. AgNPs yang terbentuk dianalisis dengan Spektrofotometri UV-Vis untuk mengevaluasi absorbansi surface plasmon resonance (SPR) AgNPs tersebut di daerah panjang gelombang 400-500 $\mathrm{nm}$. Proses sintesis sangat dipengaruhi oleh pH, waktu reaksi, dan rasio mol reaktan. Sintesis hanya berlangsung pada $\mathrm{pH}$ 11, dan pada waktu reaksi 30 menit, ukuran partikel AgNPs yang diperoleh adalah $12 \pm 7 \mathrm{~nm}$. Waktu reaksi yang semakin lama dapat meningkatkan kemampuan reduksi asam $p$ aminobenzoat dalam sintesis AgNPs namun menurunkan kemampuan stabilisasinya. Peningkatan jumlah perak nitrat relatif terhadap asam $p$-aminobenzoat dapat meningkatkan kemampuan pereduksi dan penstabil asam $p$ aminobenzoat dengan rasio mol optimum $\mathrm{AgNO}_{3}$ terhadap asam p-aminobenzoat adalah 5:100.

Kata Kunci: agen penstabil; agen pereduksi; asam p-aminobenzoat; nanopartikel perak

\section{INTRODUCTION}

Nowadays, synthesis of silver nanoparticles (AgNPs) has become a very popular topic among scientist because of the wide application of AgNPs as antimicrobial agent [1-3], in environmental treatments, such as air, water, and surface disinfection [4], and as chemical sensors for organic solvent vapors [5], ammonia [6], Sudan dye [7], chlorine dioxide [8], herbicides [9], copper ions [10], and lead ions [11]. Among all AgNPs synthesis methods, chemical reduction is very popular because of its convenience, relatively low cost, and likely can be produced on a large

* Corresponding author.

Email address : sjuari@ugm.ac.id scale [12]. In this method, a silver ion precursor in a solution is reduced by a reducing agent to become AgNPs. In order to prevent the agglomeration that will damage the colloidal system of AgNPs, stabilizing agent was added to the system [13]. Many studies have been conducted by using different chemicals as reducing and stabilizing agents [7,14-19]. However, AgNPs synthesis by using only one chemical as both reducing and stabilizing agent is preferable than using two different chemicals because the use of less chemicals will make the synthesis process become more environmental friendly. Some previous studies showed that hydroxyl group can act as reducing agent 
and benzoic acid group can act as stabilizing agent [20]. Beside hydroxyl group, amino group also can be used to reduce silver ion to become silver nanoparticle [22]. Organic compounds which have hydroxyl or amino group and carboxylic acid group were predicted to have ability to act as reducing and stabilizing agent. This prediction has been proved by Gusrizal et al., who had synthesized silver nanoparticle by using benzoic acid derivatives with hydroxy phenolic group as reducing and stabilizing agent in the AgNPs synthesis [20-21]. Nevertheless, the use of benzoic acid derivatives with amino group in the silver nanoparticle synthesis has not been discovered yet. This paper describe the ability of benzoic acid derivatives with amino group substituent to reduce silver ion and stabilize the formed AgNPs. Furthermore, comparison between AgNPs which was synthesized by using benzoic acid derivative with amino group substituent and those which was synthesized by using benzoic acid derivative with hydroxyl group substituent was presented in order to discover the effect of substituent changing in the synthesis process and the stability of the synthesized AgNPs.

In this research, $p$-aminobenzoic acid was used as both reducing and stabilizing agent in AgNPs synthesis. The amino group was predicted to reduce the $\mathrm{Ag}^{+}$ions to become $\mathrm{Ag}^{0}$, and the carboxylate groups will stabilize the formed AgNPs. In order to critically examine the influence of synthesis parameter to the performance of $p$-aminobenzoic acid as both reducing agents of $\mathrm{Ag}^{+}$to $\mathrm{Ag}^{0}$ and stabilizing agents for the formed AgNPs, some synthesis parameters were studied and surface plasmon resonance (SPR) spectra of the resulted AgNPs was observed. Furthermore, a comparison was made with another benzoic acid derivatives to compare the effects of amino group substitution to the benzoic acid compound. The particle size of the AgNPs synthesized at optimum condition was also determined.

\section{EXPERIMENTAL SECTION}

\section{Materials}

The materials used were silver nitrate (Merck) as precursor of AgNPs, $p$-aminobenzoic acid (Sigma Aldrich) as reducing and stabilizing agent, and sodium hydroxide and hydrochloric acid (Merck) as $\mathrm{pH}$ adjuster. All reagents were used as received without further purification.

\section{Instrumentation}

The characterization of AgNPs was performed by using UV-Vis Spectrophotometer (Shimadzu PharmaSpec UV-1700) and Transmission Electron Microscope (JEOL JEM-1400).

\section{Procedure}

\section{Synthesis of silver nanoparticles}

A $5 \mathrm{~mL}$ silver nitrate solution with concentration of $0.3 \times 10^{-3} \mathrm{~mol} / \mathrm{L}$ was added to $5 \mathrm{~mL} \mathrm{pH}$-adjusted $p$ aminobenzoic acid with concentration of $10 \times 10^{-3} \mathrm{~mol} / \mathrm{L}$ in a test tube with volume ratio of 1:1. The mixture was then heated in a boiling water bath for several minutes until it turned yellow which indicated that the AgNPs were formed. After the reaction was complete, the mixture was cooled in tap water and transferred to a small bottle for further analysis. In order to evaluate the reducing and stabilizing performance of $p$ aminobenzoic acid, effect of some reaction parameters, i.e. $\mathrm{pH}(1-14)$, reaction time $(0,15,30,45,60 \mathrm{~min})$, and mole ratio of the reactants (mole of $\mathrm{AgNO}_{3}$ :mole of $p$ aminobenzoic acid $=1: 100,3: 100,5: 100,8: 100$, and 10:100) was examined

\section{Characterization of silver nanoparticles}

AgNPs were characterized using UV-Vis spectrophotometry. The resulted AgNPs colloid was poured into a quartz cuvette with $1 \mathrm{~cm}$ optical path length and scanned at $200-800 \mathrm{~nm}$ wavelength. The UV-Vis spectra was measured right after the reaction and several days after the reaction to evaluate the stability performance of $p$-aminobenzoic acid.

TEM analysis was performed to evaluate the particle size and shape of the synthesized AgNPs. A copper grid was first immersed to the AgNPs colloid and then dried at room temperature. The image was taken by using $120 \mathrm{kV}$ accelerating voltage. The particle size of AgNPs was calculated by using the scale provided in the micrograph and image $\mathrm{J}$ software.

\section{RESULT AND DISCUSSION}

\section{The Effect of Acidity}

In this study, the $\mathrm{pH}$ of $p$-aminobenzoic acid solution was varied from 1 to 14 to find out the effect of the solution acidity on the AgNPs synthesis. The synthesis process was evaluated with UV-Vis Spectrophtometer. If the absorbance band in the wavelength range of $400-500 \mathrm{~nm}$ is observed, it means AgNPs are formed. It because AgNPs has SPR properties which can be clarified by the yellow colour of the solution and also the occurence of absorbance band in the wavelength range of 400-500 nm [5]. From the spectra in the Fig. 1, it can be seen that the AgNPs is only formed at $\mathrm{pH} 11$. The synthesis of AgNPs by using derivatives of benzoic acid are usually conducted under basic conditions, because the benzoic acid group will be deprotonated and the formed negative charge can interact easily with the positive metal ion 
[23]. Beside that, in the mechanism of silver ion reduction, the silver ion was neutralize with the base and $\mathrm{Ag}_{2} \mathrm{O}$ aggregates were formed. The surface of $\mathrm{Ag}_{2} \mathrm{O}$ macrophase which contact with water is then hydrated and $\mathrm{AgOH}$ is formed. $\mathrm{AgOH}$ is then reach an equilibrium with $\mathrm{Ag}^{+}$and $\mathrm{OH}^{-}$(equation 1). Therefore silver ion will be absorbed on $\mathrm{Ag}_{2} \mathrm{O}$ surface (Equation 2) [24].

$$
\mathrm{Ag}_{2} \mathrm{O}+\mathrm{H}_{2} \mathrm{O} \rightleftharpoons 2 \mathrm{AgOH} \rightleftharpoons 2 \mathrm{Ag}^{+}+2 \mathrm{OH}^{-}
$$$$
\mathrm{Ag}_{2} \mathrm{O}+\mathrm{Ag}^{+} \rightleftharpoons \mathrm{Ag}^{+}\left(\mathrm{Ag}_{2} \mathrm{O}\right)
$$

In an appropriate $\mathrm{pH}$, the equilibrium of Equation 1 and 2 occurs simultaneously with the deprotonation of amino and benzoic acid group from $p$-aminobenzoic acid so the reduction proceeds. As $\mathrm{pH}$ goes higher, the amount of silver ion in solution decreases because the equilibrium shifts to $\mathrm{Ag}_{2} \mathrm{O}$ and it is then solidified at the bottom of the tube. On the other hand, as the $\mathrm{pH}$ decreasing, the amount of deprotonated amino or carboxylic acid group from $p$-aminobenzoic acid also decreases. The optimum $\mathrm{pH}$ found in this study was the same as obtained by others which used reducing agents hydroxybenzoic acid [20] and dihydroxybenzoic acid [21].

\section{The Effect of Reaction Time}

Reaction time is also an important factor in affecting the performance of $p$-aminobenzoic acid as reducing agent in AgNPs synthesis. A reducing agent which gives faster reduction shows greater reduction performance than other reducing agent because it can interact more easily with the silver ion and reduce it to AgNPs in shorter time. In this study, the reduction was monitored at a time interval by using UV-Vis spectrophotometry from 0 to $60 \mathrm{~min}$. The result is shown in Fig. 2. It is seen clearly that the SPR absorbance of AgNPs increases along with the increase of reaction time.

In order to evaluate the effect of reaction time on the stabilization performance of $p$-aminobenzoic acid, the solution was stored for 30 days and its absorbance was re-measured. Based on the re-measurement result in Fig. 3, it can be shown that the AgNPs produced at 60 min reaction time was less stable because its absorbance decreased after 30 days. On the other hand, AgNPs produced at 30 min reaction time was more stable because its absorbance did not decrease, even it increased slightly after storing 30 days. It is assumed that the longer solution heated, the molecules in the solution become more active, even when the heating process is stopped. The more active molecules will react further so the reduction process still occur although the heating has been stopped. Prolonged reduction may lead to bigger size of AgNPS and then decrease the stability. It can be concluded that longer reaction time gives

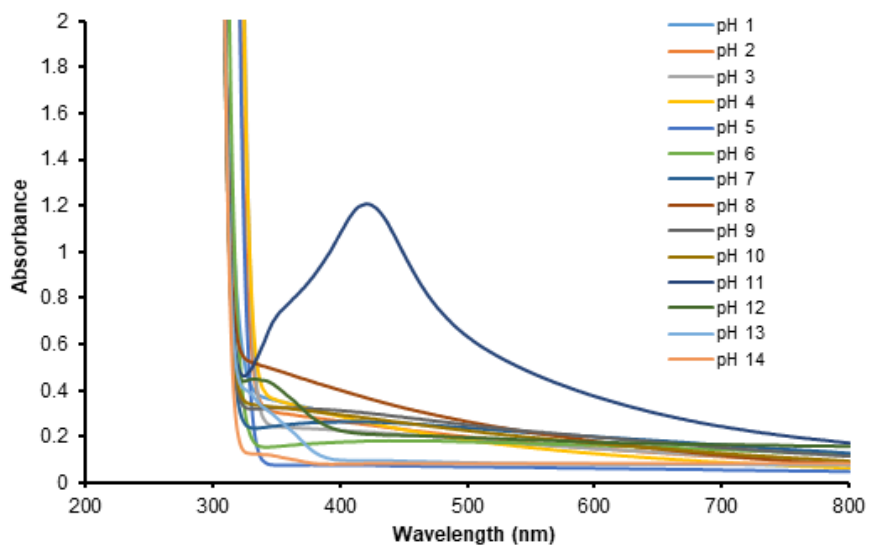

Fig 1. The spectra of the reaction product between of $0.3 \times 10^{-3} \mathrm{~mol} / \mathrm{L} \mathrm{AgNO}_{3}$ and $50 \times 10^{-3} \mathrm{~mol} / \mathrm{L} \quad p$ aminobenzoic acid at various $\mathrm{pH}$

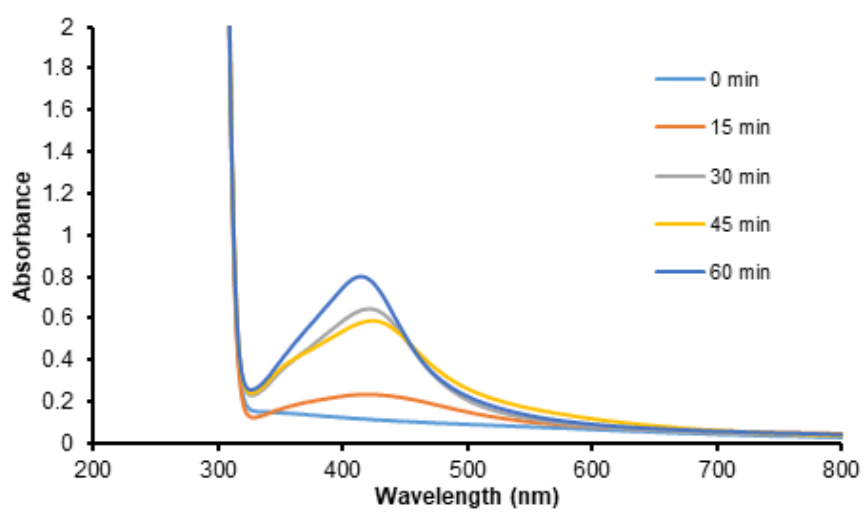

Fig 2. The SPR spectra of AgNPs made from $0.3 \times 10^{-3}$ $\mathrm{mol} / \mathrm{L} \mathrm{AgNO}_{3}$ and $10 \times 10^{-3} \mathrm{~mol} / \mathrm{L} p$-aminobenzoic acid at $\mathrm{pH} 11$ with various reaction times

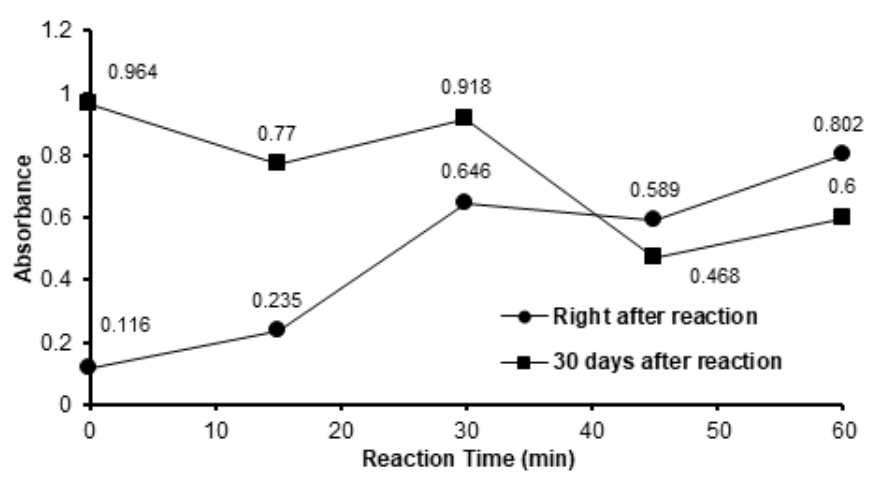

Fig 3. The SPR absorbance of fresh-synthesized and 30 days-stored AgNPs which has been made at various reaction times from $0.3 \times 10^{-3} \mathrm{~mol} / \mathrm{L} \mathrm{AgNO}_{3}$ and $10 \times 10^{-3} \mathrm{~mol} / \mathrm{L} p$-aminobenzoic acid at $\mathrm{pH} 11$

better reducing performance of $p$-aminobenzoic acid, but decreasing its stabilization performance. On the contrary, faster reaction time gives higher stabilizing performance of $p$-aminobenzoic acid, but decreasing its 
reducing performance. It happens because the heat from the heating process is still working for the molecules even when the heating process is terminated. It makes the reduction still takes place and the particle size will be smaller. The smaller particle size usually has worse stability.

In order to obtain good reducing and stabilizing performance of $p$-aminobenzoic acid, the reaction time 30 min was chosen as the optimum reaction time. This optimum reaction time is slower than that using hydroxybenzoic acid as reducing agent, which needs 15 min to reach its optimum [20] but it was faster than $o, p$ dihydroxybenzoic acid which needs $60 \mathrm{~min}$ at the same temperature [21].

\section{The Effect of Mole Ratio}

In addition to acidity and reaction time, mole ratio of reactants is also very important in affecting the formation of AgNPs. The spectra of AgNPs produced from the reaction of various mole ratios of $\mathrm{AgNO}_{3}$ to $p$ aminobenzoic acid are shown in Fig. 4. It can be seen that more silver nitrate relative to $p$-aminobenzoic acid gives higher SPR absorbance of AgNPs and reaches the highest one at mole ratio 8:100. If the proportion of silver nitrate was further enhanced to reach mole ratio 10:100, the reaction did not occur because the excessive amount of silver ion made the equilibrium in equation 1 shift to the left and increased the amount of $\mathrm{Ag}_{2} \mathrm{O}$ which would be thenl solidified at the bottom of the tube. It means that reactant mole ratio influences the reduction performance of $p$-aminobenzoic acid in the synthesis of AgNPs.

This study also evaluate the effect of reactant mole ratio to the stabilization performance of AgNPs and the result is shown in Fig. 5. The AgNPs that were synthesized at mole ratio $\mathrm{AgNO}_{3}$ and $p$-aminobenzoic acid 8:100, they were soon precipitated after 1 month. The AgNPs synthesized by $\mathrm{AgNO}_{3}$ and $p$-aminobenzoic acid at mole ratio 3:100 had bad stability as indicated by the enhancement of peak absorbance up to $42 \%$ and shift of peak to wavelength $2 \mathrm{~nm}$ smaller after 16 weeks. The AgNPs formed from mole ratio 5:100 of $\mathrm{AgNO}_{3}$ and $p$-aminobenzoic acid had better stability because the absorbance enhancement was only $9 \%$ and it was not accompanied by peak shift. The stability of AgNPs reported in this study is less stable than AgNPs synthesized using p-hydroxybenzoic acid as reducing and stabilizing agent. With $\mathrm{p}$-hydroxybenzoic acid as reducing and stabilizing agent, change of the peak absorbance was only $1 \%$ after 18 weeks storage[20]. This fact may indicate that amino groups has less stabilizing performance than phenoxy hydroxyl group in benzoic acid derivatives.

\section{Characterization of AgNPs}

The AgNPs particle size was further characterized for their particle size using TEM. The particle size of the synthesized AgNPs can exhibit the reducing ability of the used reducing agent. If the reducing agent has

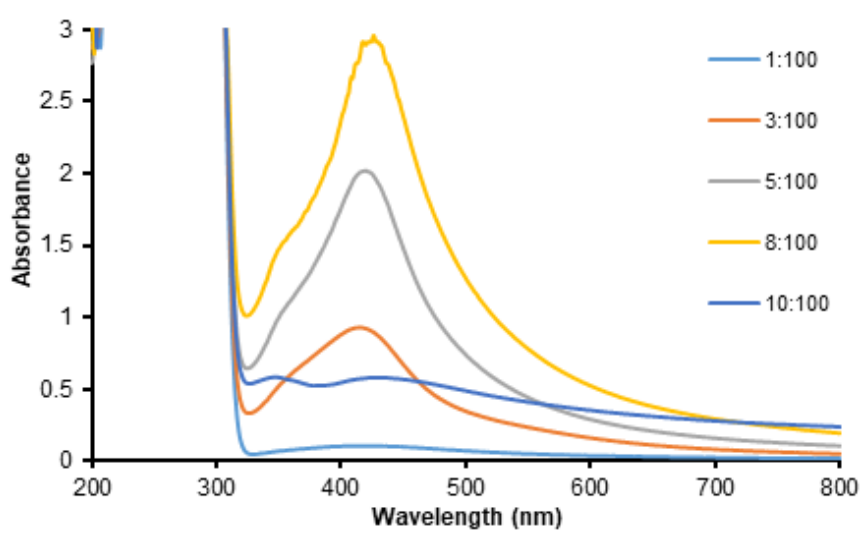

Fig 4. The SPR Spectra of AgNPs produced from the reaction of various mole ratios of $\mathrm{AgNO}_{3}$ with $p$ aminobenzoic acid at $\mathrm{pH} 11$
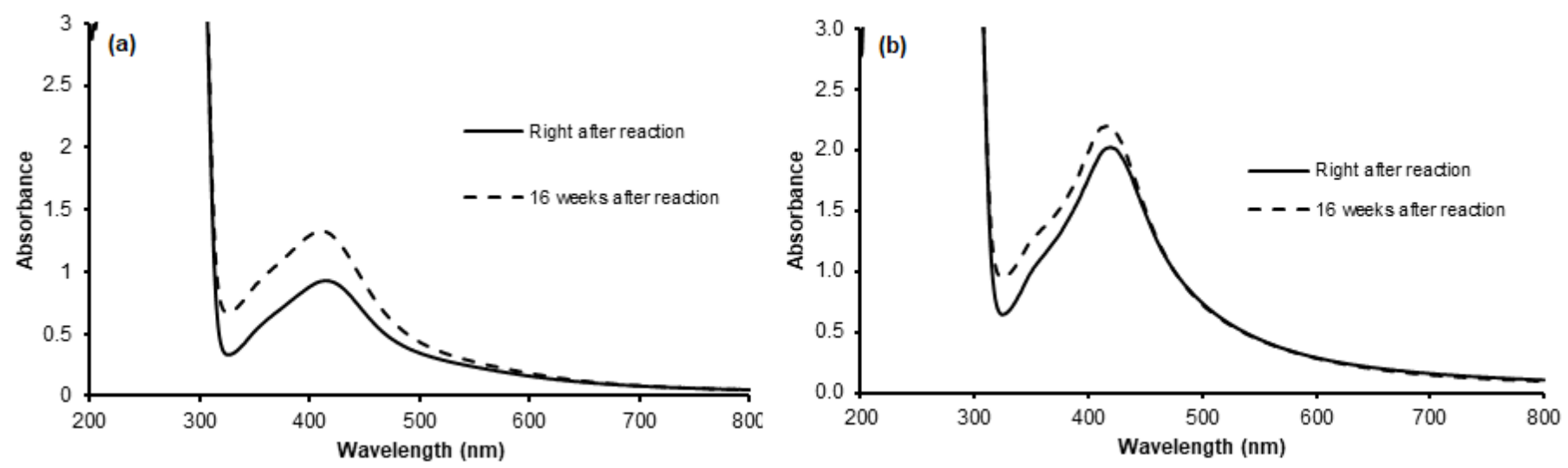

Fig 5. The SPR spectra of fresh and 16 weeks-stored AgNPs produced from the reaction of $\mathrm{AgNO}_{3}$ with $p$ aminobenzoic acid at pH 11 with mole ratio (a) 3:100 and (b) 5:100 ( $\mathrm{AgNO}_{3}: p$-aminobenzoic acid) 

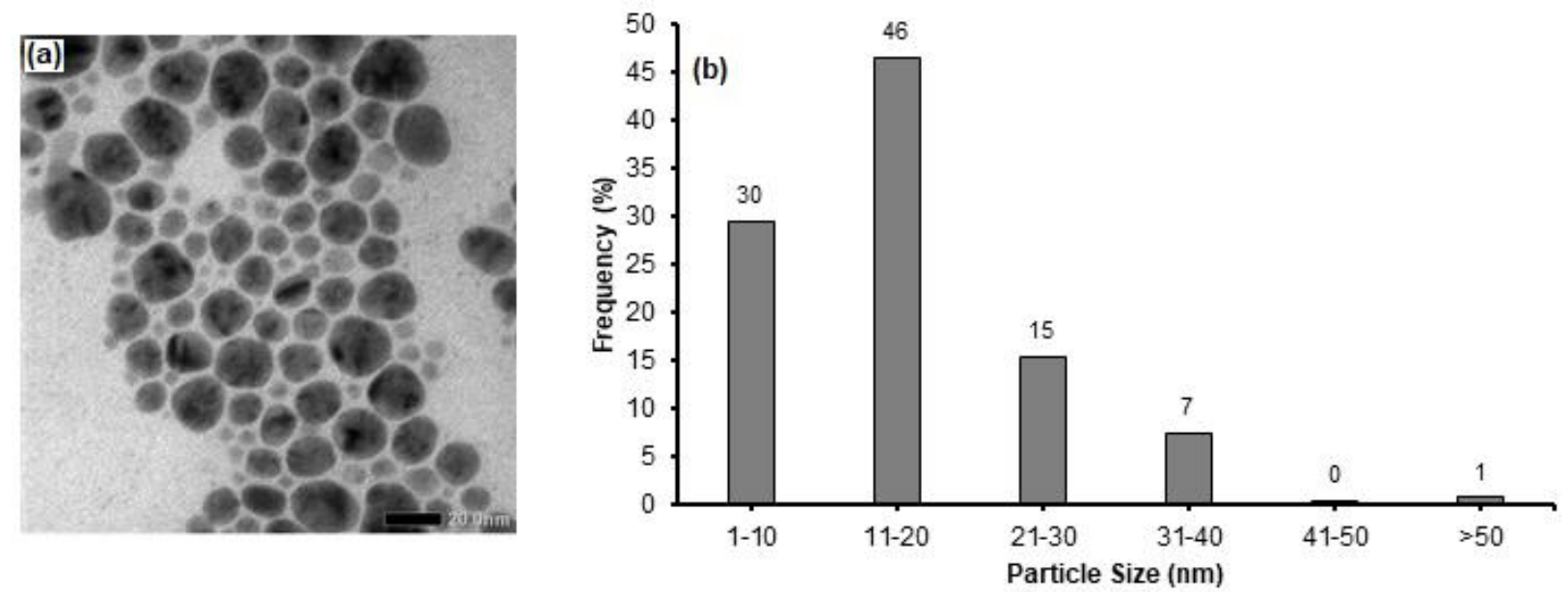

Fig 6. The TEM images (a) and particle size distribution (b) of AgNPs synthesized by using $0.3 \times 10^{-3} \mathrm{~mol} / \mathrm{L} \mathrm{AgNO}_{3}$ and $10 \times 10^{-3} \mathrm{~mol} / \mathrm{L} p$-aminobenzoic acid at $\mathrm{pH} 11$ and a reaction time of $30 \mathrm{~min}$

Table 1. The comparison of average particle size of AgNPs which synthesized using different benzoic acid derivatives.

\begin{tabular}{lcc}
\hline Reducing Agent & $\begin{array}{c}\text { AgNPs Average } \\
\text { Particle Size (nm) }\end{array}$ & Reference \\
\hline$p$-hydroxybenzoic acid & $26 \pm 11$ & {$[20]$} \\
o,p-dihydroxybenzoic acid & $45 \pm 4$ & {$[21]$} \\
$p$-aminobenzoic acid & $12 \pm 7$ & This research \\
\hline
\end{tabular}

better reducing performance, it will interact more easily with the silver ion on the surface of $\mathrm{Ag}_{2} \mathrm{O}$ and reduce more silver ion from $\mathrm{Ag}_{2} \mathrm{O}$ surface. If the reduction takes place further, it decreases the particle size of $\mathrm{Ag}_{2} \mathrm{O}$ until the AgNPs formed. Therefore if the reducing agent has better reducing performance, it will result on smaller particle size in the AgNPs synthesis.

TEM image of the synthesized AgNPs at pH 11, reaction time $30 \mathrm{~min}$, and reactant mole ratio $3: 100$ $\left(\mathrm{AgNO}_{3}\right.$ to $p$-aminobenzoic acid) along with particle size distribution of the synthesized AgNPs us shown in Fig. 6. It can be seen that AgNPs had spherical shape. The average of particle sizes was $12 \pm 7 \mathrm{~nm}$. The comparison between AgNPs particle size obtained in this study and that obtained by using other reducing agents reported in literatures is given in Table 1. AgNPs which are synthesized using $p$-aminobenzoic acid is smaller in particle size than those synthesized using hydroxybenzoic acid $[20,25]$ and dihydroxybenzoic acid [21]. In term of this particle size, $p$-aminobenzoic acid has better reducing performance than $p$-hydroxybenzoic acid and $o, p$-dihydroxybenzoic acid.

The almost same AgNPs size obtained by Sulistiawaty et al. [26] which use glucose as reducing agent with tween- 20 and gelatin as stabilizing agent. The average size of AgNPs without stabilizing agent, AgNPs with tween-20, and those with gelatin were 11.73, 17.54, and $9.68 \mathrm{~nm}$, respectively. However, these AgNPs have low stability, which are indicated by the decrease of the peak of SPR absorbance of AgNPs after 2 weeks storage. As a result, $p$-aminobenzoic acid is more preferable to be used as both reducing and stabilizing agent in the synthesis of AgNPs than glucose.

\section{CONCLUSION}

Silver nanoparticles were successfully synthesized by using $p$-aminobenzoic acid as reducing and stabilizing agents. The particle shapes of the resulting nanoparticles were spherical with size of $12 \pm$ $7 \mathrm{~nm}$. The synthesis process was highly affected by $\mathrm{pH}$, reaction time, and mole ratios of the reactants. The synthesis only occurred at $\mathrm{pH} 11$. Longer reaction time increased the reducing performance of $p$-aminobenzoic acid in AgNPs synthesis but decreased its stabilizing performance. The optimum reaction time and mole ratio between $\mathrm{AgNO}_{3}$ and $p$-aminobenzoic acid were 30 min and 5:100 $\left(\mathrm{AgNO}_{3}\right.$ to $p$-aminobenzoic acid), respectively. The reducing and stabilizing performances of $p$-aminobenzoic acid were also dependent on the interaction of the functional groups of $p$-aminobenzoic acid with AgNPs. Further research is needed to discover the interaction between the reducing and stabilizing agent with the precursors in the solution. 


\section{ACKNOWLEDGEMENT}

The authors expressed special thanks to Ministry of Research and Higher Education of Republic of Indonesia which has partly supported this research activities through Universitas Gadjah Mada, Yogyakarta, in the form of Penelitian Unggulan Perguruan Tinggi Grant and by providing scholarship of Master Education Program Leading to Doctoral Degree for Excellent Graduates (PMDSU) to the first author with contract number of 1984/UN1.P.III/DIT-LIT/LT/2017.

\section{REFERENCES}

[1] Rodríguez-Argüelles, M.C., Sieiro, C., Cao, R., and Nasi, L., 2011, Chitosan and silver nanoparticles as pudding with raisins with antimicrobial properties, $J$. Colloid Interface Sci., 364 (1), 80-84.

[2] Prabhu, S., and Poulose, E.K., 2012, Silver nanoparticles: mechanism of antimicrobial action, synthesis, medical applications, and toxicity effects, Int. Nano Lett., 2, 32.

[3] Fouda, M.M.G., El-Aassar, M.R., and Al-deyab, S.S., 2013, Antimicrobial activity of carboxymethyl chitosan/polyethylene oxide nanofibers embedded silver nanoparticles, Carbohydr. Polym., 92 (2), 1012-1017.

[4] Tran, Q.H., Nguyen, V.Q., and Le, A.T., 2013, Silver nanoparticles: Synthesis, properties, toxicology, applications and perspectives, Adv. Nat. Sci.: Nanosci. Nanotechnol., 4 (3), 43001-45018.

[5] Quaranta, A., Carturan, S., Bonafini, M., Maggioni, G., Tonezzer, M., Mattei, G., Fernandez, C.J., Mea, G.D., and Mazzoldi, P., 2006, Optical sensing to organic vapors of fluorinated polyimide nanocomposites containing silver nanoclusters, Sens. Actuators, B, 118 (1-2), 418-424.

[6] Pandey, S., Goswami, G.K., and Nanda, K.K., 2012, Green synthesis of biopolymer-silver nanoparticle nanocomposite: An optical sensor for ammonia detection, Int. J. Biol. Macromol., 51 (4), 583-589.

[7] Wu, L.P., Li, Y.F., Huang, C.Z., and Zhang, Q., 2006, Visual detection of Sudan dyes based on the plasmon resonance light scattering signals of silver nanoparticles, Anal. Chem., 78 (15), 5570-5577.

[8] Kang, C.Y., Xi, D.L., Chen, Y.Y., and Jiang, Z.L., 2008, Determination of trace chlorine dioxide based on the plasmon resonance scattering of silver nanoparticles, Talanta, 74 (4), 867-870.

[9] Dubas, S.T., and Pimpan, V., 2008, Humic acid assisted synthesis of silver nanoparticles and its application to herbicide detection, Mater. Lett., 62 (17-18), 2661-2663.

[10] Ratnarathorn, N., Chailapakul, O., Henry, C.S., and Dungchai, W., 2012, Simple silver nanoparticle colorimetric sensing for copper by paper-based devices, Talanta, 99, 552-557.

[11] Balakumar, V., Prakash, P., Muthupandi, K., and Rajan, A., 2017, Nanosilver for selective and sensitive sensing of saturnism, Sens. Actuators, $B$, 241, 814-820.

[12] Zahra, Q., Fraz, A., Anwar, A., Awais, M., and Abbas, M., 2016, A mini review on the synthesis of Ag-nanoparticles by chemical reduction method and their biomedical applications, NJES, 9 (1), 17.

[13] Ahmad, M.B., Tay, M.Y., Kamyar, S., Hussein, M.Z., and Lim, J.J., 2011, Green synthesis and characterization of silver/chitosan/polyethylene glycol nanocomposites without any reducing agent, Int. J. Mol. Sci., 12 (8), 4872-4884.

[14] Wang, W., Chen, X., and Efrima, S., 1999, Silver nanoparticles capped by long-chain unsaturated carboxylates, J. Phys. Chem. B, 103 (34), 72387246.

[15] Pastoriza-Santos, I., and Liz-Marzán, L.M., 2002, Synthesis of silver nanoprisms in DMF, Nano Lett., 2 (8), 903-905.

[16] Raveendran, P., Fu, J., and Wallen, S.L., 2003, Completely "green" synthesis and stabilization of metal nanoparticles, J. Am. Chem. Soc., 125 (46), 13940-13941.

[17] Laudenslager, M.J., Schiffman, J.D., and Schauer, C.L., 2008, Carboxymethyl chitosan as a matrix material for platinum, gold, and silver nanoparticles, Biomacromolecules, 9 (10), 26822685.

[18] Hassabo, A.G., Nada, A.A., Ibrahim, H.M., and Abou-Zeid, N.Y., 2015, Impregnation of silver nanoparticles into polysaccharide substrates and their properties, Carbohydr. Polym., 122, 343-350.

[19] Huang, L., Zhai, M.L., Long, D.W., L., Peng, J., Xu, L., Wu, G.Z., Li, J.Q., and Wei, G.S., 2008, UV-induced synthesis, characterization and formation mechanism of silver nanoparticles in alkalic carboxymethylated chitosan solution, J. Nanopart. Res., 10 (7), 1193-1202.

[20] Gusrizal, G., Santosa, S.J., Kunarti, E.S., and Rusdiarso, B., 2016, Dual function of $p$ hydroxybenzoic acid as reducing and capping agent in rapid and simple formation of stable silver nanoparticles, Int. J. ChemTech Res., 9 (9), 472 482.

[21] Susanthy, D., Fadliah, Wahyuni, E.T., and Santosa, S.J., 2017, Synthesis of silver nanoparticles using o-hydroxybenzoic, phydroxybenzoic, and o,p-dihydroxybenzoic acids as reducing agents, Mater. Sci. Forum, 901, 2631. 
[22] Hussain, J.I., Kumar, S., Hashmi, A.A., and Khan, Z, 2011, Silver nanoparticles: Preparation, characterization, and kinetics, Adv. Mater. Lett., 2 (3), 188-194.

[23] Patil, R.S., Kokate, M.R., Jambhale, C.L., Pawar, S.M., Han, S.H., and Kolekar, S.S., 2012, One-pot synthesis of PVA-capped silver nanoparticles their characterization and biomedical application, Adv. Nat. Sci.: Nanosci. Nanotechnol., 3 (1), 015013.

[24] Litvin, V.A., Galagan, R.L., and Minaev, B.F., 2012, Kinetic and mechanism formation of silver nanoparticles coated by synthetic humic substances, Colloids Surf., A, 414, 234-243.

[25] Gusrizal, G., Santosa, S.J., Kunarti, E.S., and Rusdiarso, B., 2017, Synthesis of silver nanoparticles by reduction of silver ion with $\mathrm{m}$ hydroxybenzoic acid, Asian J. Chem., 29 (7), 1417-1422.

[26] Sulistiawaty, L., Sugiarti, S., and Darmawan, N., 2015, Detection of $\mathrm{Hg}^{2+}$ metal ions using silver nanoparticles stabilized by gelatin and Tween-20, Indones. J. Chem., 15 (1), 1-8. 